\title{
TO THE DEVELOPMENT OF INNOVATIVE MINERAL ADDITIVES BASED ON ALLOY OF Fe AND Co ANTAGONISTS AS AN EXAMPLE
}

\section{E.A. SIZOVA ${ }^{1,}$, , S.A. MIROSHNIKOV', S.V. LEBEDEV ${ }^{2}$, A.V. KUDASHEVA', N.I. RYABOV1}

\begin{abstract}
${ }^{1}$ All-Russian Research Institute of Beef Cattle Breeding, Federal Agency of Scientific Organizations, 29, ul. 9 Yanvarya, Orenburg, 460000 Russia, e-mail sizova-178@ya.ru,vniims.or@mail.ru;

${ }^{2}$ Orenburg State University, 13, prosp. Pobedy, Orenburg, 460018 Russia, e-mail elenka_rs@mail.ru, osipaylova@mail.ru Acknowledgements:

Hematological studies were performed using standard techniques in the Laboratory of Agroecology of Nanomaterials and Test Center of All-Russian Research Institute of Beef Cattle Breeding (accreditation certificate RA. RU.21PF59 from 12/02/15). Analysis of chemical elements was performed in the laboratory of ANO Center for Biotic Medicine, Moscow (accreditation certificate GSEN.RU.TSAO.311, registration number in the State Register ROSS RU. 0001.513118).
\end{abstract}

Supported by Russian Scientific Foundation (project № 14-36-00023)

Received May 25, 2016

\section{Abstract}

The problem of joint use of antagonist elements in the nutrition of farm animals is solved through a separate feeding with such trace elements and through an increase in the dosage of substances. The unique properties of nanomaterials allow us to suggest the promising alternative solutions by combining antagonists in a single drug, i.e. ultra-fine powders of metal alloys. In this paper, we for the first time compared the growth, haematological and biochemical parameters of broiler chickens (Russian cross Smena 7) after feeding them with individual salts of two microelements or their alloy in the form of nanoparticles. The pair of antagonists (iron and cobalt) was chosen due to the same mechanism of their absorption in intestine. Salts $\mathrm{FeSO}_{4} \cdot 7 \mathrm{H}_{2} \mathrm{O}$ and $\mathrm{CoCl}_{2}$ (group I) or the derived nanoparticles $(\mathrm{d}=62.5 \pm 0.6 \mathrm{~nm}$ ) of the metal alloy (group II) were used as sources of iron and cobalt and mineral supplement. After calculation of the proportion of common microelement pool to the value of its entry with fodder expressed in percentage, the excess of iron up to $50.0 \%$ was registered in the group when alloy nanoparticles applied (comparing to the pure iron), and the excess of cobalt was $34.7 \%$. Biological significance of the obtained values is the amount of the element deposited in the body expressed in grams per 100 grams of element entering with the incoming feed. In this case, growth rate increased and metabolism changes in chicken were registered. During the experiment, weight gain exceeded the control in group I by $6 \%$ ( $p \leq 0.05)$, and in group II by $11 \%(\mathrm{p} \leq 0.001)$. Feed costs for growing chickens in the control group was $2.48 \mathrm{~kg}$ that is by 9.3 and $13.7 \%$ more than in groups I and II, respectively. Using Co-Fe alloy increased weight gain by $4.1 \%$ ( $\mathrm{p} \leq 0.05)$ compared with group I while the food consumption reduced by $4.8 \%$. Creatinine content in groups I and II was $63.9 \%(\mathrm{p} \leq 0.01)$ and $38.3 \%(\mathrm{p} \leq 0.05)$ higher than in the control, respectively. At the same time, the blood urea concentration in group I, and blood glucose level in group II increased compared to control by $38.5 \%(\mathrm{p} \leq 0.05)$ and $36.5 \%(\mathrm{p} \leq 0.05)$, respectively. However, the revealed increase of iron pool in group II was not associated with a significant increase in iron concentration in blood serum in relation to that in group I (it was possibly due to the homeostatic regulation, as an excess of iron may lead to the generation of reactive oxygen species) with a significant reduction in its concentration (by 74.3-78.3\%, p < 0.01) in control at dietary iron deficiency. Using nanoparticle preparations was accompanied by an increase in fraction of arginine in liver of experimental chickens up to $8.10 \pm 0.105 \%$ as compared with the control value of $5.05 \pm 0.075 \%$ (note, the growth-promoting effects of L-arginine were described in literature). elements

Keywords: nanoparticles of iron and cobalt, broiler chicks, growth intensity, chemical

In humans and animals, chemical elements interact with other elements $[1,2]$, amino acids [3], ferments [4], etc., in metabolism. The expediency of investigating such interactions is determined by the necessity of prenosological diagnostics and elementosis treatment, diet adjustments [5], and evaluation of true diet densities $(6,7)$. Historically, special attention has been paid to the dosing of 
a small group of microelements (iron, zinc, copper, etc.) the absorption of which depends on their antagonists. Methods appeared to level the negative effect of some substances on the absorption of microelements, in particular, based on separate inclusion of antagonist substances in the diet [9]. Such intake of zinc and iron supplements has a positive effect on the growth and development of children in their first year of life [10]. The dosing schedules for a number of vitamin-mineral complexes (VMC) are based on the principle of separate use of antagonist microelements. The most famous Russian representative of this line of preparations is VMC Alphabet. Its efficiency is confirmed by a number of research demonstrating the facts of increased biological availability of microelements, including zinc, iron, etc. [11].

It seems that with the beginning of nanomaterials production, a similar result may be achieved by using metal nanoparticles. The substances of this class with the size of particles of about $10 \mathrm{~nm}$ are characterized by low toxicity [12]. It is reported that the preparations of metal nanoparticles (in particular, iron) are substantially superior to the respective mineral salts by their bio-availability $[13,14]$. A number of works demonstrate the expediency of using nanosized microelements in diets for animals and poultry [15-18].

The properties of nanoparticles (including their high penetration power) allowed us to assume the high potential of the alternative solution - a combination of antagonist microelements into one preparation in the form of ultradisperse nano-powders of their alloys.

In this work, we have for the first time compared the growth, hematological and biochemical indicators in broiler chickens of domestic cross when feeding individual salts of two microelements or their nanosized alloy. The pair of antagonists (iron and cobalt) was selected due to the same mechanism of their intestinal absorption [19, 20]. According to our hypothesis, it should be expected that the preparation of $\mathrm{Fe}$ and $\mathrm{Co}$ alloy nanoparticles will have an advantage over their mineral salts by bioavailability of these elements in vivo and their production effect.

The purpose of the experiment was to test the approach for optimizing the mineral feeding of broiler chickens by introducing the nanoparticles of the alloy of two antagonist microelements into the diet.

Technique. The nanoparticles of the iron and cobalt alloy were obtained by high-temperature condensation (Migen-3, Institute for Energy Problems of Chemical Physics, RAS, Moscow) in accordance with a described methodology [21]. The material attestation of the preparations included electronic scanning and transmission microscopy (JSM 7401F and JEM-2000FX, JEOL, Japan). The X-ray phase analysis was conducted using a diffractometer DRON-7 (Burevestnik, Russia). According to the attestation results, the size of nanoparticles was $62.5 \pm 0.6 \mathrm{~nm}$ with a Fe:Co ratio of 7:3. To obtain lyosols for their further feeding to chickens, the water suspensions of nanoparticles were for 30 minutes exposed to ultrasound using a disperser UZDN-2T (Akadempribor, Russia) (35 kHz, 300/450 W, $10 \mathrm{mcA})$.

The tests were conducted on Smena 7 broiler chickens in a vivarium (Orenburg State University). The keeping conditions and test procedures met the instructions and recommendations provided for by the national regulations (Order of the USSR Ministry of Health No. 755 d/d August 12, 1977) and The Guide for Care and Use of Laboratory Animals (National Academy Press, Washington, D.C., 1996). All efforts were taken to minimize the suffering of animals and to reduce the number of samples used.

A total of 100 hens of 1 day old were selected for the experiment. The chickens with assigned individual numbers (leg plastic tags) were weighed and 
further kept in the same conditions. At the age of 2 weeks, based on individual daily weighing data and food consumption, three groups (one control and two test groups) were formed, each including 30 hens, by analogue pairs.

The complete feeds used were made with regard to the recommendations [22]. The poultry basic diet (BD) included the following ingredients: at the age of 14-28 days - wheat $(320 \mathrm{~g} / \mathrm{kg})$ and barley $(10 \mathrm{~g} / \mathrm{kg})$, sunflower cake $(184 \mathrm{~g} / \mathrm{kg})$, soy bean meal $(200 \mathrm{~g} / \mathrm{kg})$, fish flour $(40 \mathrm{~g} / \mathrm{kg})$, vegetable oil $(60 \mathrm{~g} / \mathrm{kg})$, corn grain $(163 \mathrm{~g} / \mathrm{kg})$, wheat bran $(10 \mathrm{~g} / \mathrm{kg})$, limestone $(10 \mathrm{~g} / \mathrm{kg})$, and common salt $(3 \mathrm{~g} / \mathrm{kg}) ;$ at the age of $29-42$ days - wheat $(182 \mathrm{~g} / \mathrm{kg})$ and barley $(50 \mathrm{~g} / \mathrm{kg})$, sunflower cake $(180 \mathrm{~g} / \mathrm{kg})$, soy bean meal $(75 \mathrm{~g} / \mathrm{kg})$, fish flour $(45 \mathrm{~g} / \mathrm{kg})$, vegetable oil $(45 \mathrm{~g} / \mathrm{kg})$, corn grains $(400 \mathrm{~g} / \mathrm{kg})$, wheat bran $(10 \mathrm{~g} / \mathrm{kg})$, limestone $(10 \mathrm{~g} / \mathrm{kg})$, and common salt $(3 \mathrm{~g} / \mathrm{kg})$. The content of vitamins and mineral salts was dosed using the premixes P5 and P6 (for the chickens of up to 28 days and older, respectively) (Koudijs MKorma, Russia) including vitamins $\mathrm{A}, \mathrm{D}, \mathrm{E}, \mathrm{K}_{3}, \mathrm{~B}_{1}, \mathrm{~B}_{2}, \mathrm{~B}_{3}, \mathrm{~B}_{4}, \mathrm{~B}_{5}$, $\mathrm{B}_{6}, \mathrm{~B}_{12}, \mathrm{~B}_{\mathrm{c}}$ and $\mathrm{H}$, and microelements $\mathrm{Fe}, \mathrm{Mn}, \mathrm{Cu}, \mathrm{Zn}$, I, Se and $\mathrm{Co}$ (with a diet dose of $2 \%$ ).

For the whole test period, the chickens from the control group received $\mathrm{BD}$, while for the other chickens from days 14 to 42 the diet was supplemented with iron (7 mg/kg of food) and cobalt $(3 \mathrm{mg} / \mathrm{kg}$ of food) with salts $\mathrm{FeSO}_{4} \cdot 7 \mathrm{H}_{2} \mathrm{O}$ and $\mathrm{CoCl}_{2}$ (group I) or nanoparticles of iron and cobalt alloy (group II) in the total amount identical to that in group I. Distilled water was used for watering.

Blood for test was taken at the age of 42 days before slaughter in the morning in a fasting state from the axillary vein into vacuum tubes (for morphological test - with EDTA as an anticoagulant, for assessment of the biochemical indicators - with the coagulation activator thrombin). The blood serum was analyzed within 3 hours after blood was taken. Upon slaughtering, the animals animals were weighed, and samples of tissues and organs were collected to assess the elementary content (the samples were immediately frozen and kept at $-18^{\circ} \mathrm{C}$ ).

The morphological indicators were determined on a hematological analyzer (URIT-2900 Vet Plus by URIT Medial Electronic Co., Ltd, China). The biochemical blood serum test was made using an automatic analyzer CS-T240 (DIRUI Industrial Co., Ltd, China) and commercial veterinary kits (DiaVetTest by DIAKON-DS, Russia; Randox Laboratories Ltd., Great Britain). The aminoacid content of liver tissues was determined by capillary electrophoresis using the Kapel system (Lumex Marketing, Russia), after the preparation of samples including drying at the temperature of up to $50{ }^{\circ} \mathrm{C}$, decreasing with petroleum ether and grinding until they passed through the sieve with square cells of $0.5 \mathrm{~mm}$.

The chemical content of biomaterials and foods after ashing was studied by atomic emission spectrometry (Optima $2000 \mathrm{~V}$, Perkin Elmer, USA) and mass spectrometry (Elan 9000, Perkin Elmer, USA) according to the manufacturer's instructions. The bio-substrates were ashed using a microwave decomposition system Multiwave-3000 (Anton Paar, Austria).

A pool of chemical elements in the body was assessed. The assessed ratio between the growth of substance pool in the organism and the amount of its consumption with food for the test period was taken as a conditional indicator of the chemical element bioavailability from food.

The statistical processing of the obtained data was done using the software package Statistica 10.0 (StatSoft Inc., USA) and Microsoft Excel. The results are provided in the form of average $(M)$ and standard average error $(m)$. The validity of differences in the indicators compared was determined by Student's $t$-test. The indicators with $\mathrm{p} \leq 0.05$ were considered valid. 
Results. As a confirmation for the working hypothesis on higher bioavailability of iron and cobalt from the nanoparticles of their alloy as compared to mineral salts, we consider the fact that by the end of the experiment the iron pool in chickens from test group II exceeded the control group by $72.4 \%(\mathrm{p} \leq 0,001)$ and was higher than Group I by $21.6 \%$ (p $\leq 0.01)$ (Fig. 1, A). The similar difference for cobalt was $59.5 \%(\mathrm{p} \leq 0.001)$ and $24.8 \%(\mathrm{p} \leq 0.05)$, respectively. The difference in the content of iron and cobalt in liver and muscles varied from $20 \%$ to $140 \%$ (see Fig. 1, B).
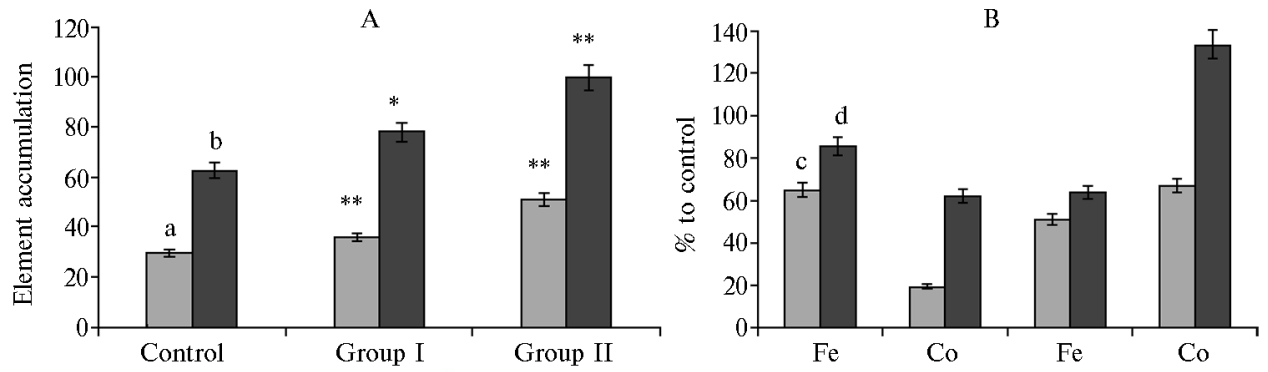

Fig. 1. The Fe and Co pool in Smena 7 cross broiler chickens of 42 days old (A) and the difference in the accumulation of these elements in tissues as compared to the control group (without supplements) (B) when Fe and Co salts (group I, $n=15$ ) or Fe and Co alloy nanoparticles (group II, $n=15$ ) used in the diet: $\mathrm{a}-\mathrm{Fe}(\mathrm{mg}), \mathrm{b}-\mathrm{Co}(\mathrm{mkg})$; $\mathrm{c}-$ group $\mathrm{I}, \mathrm{d}-$ group II (see the description of groups in the Technique section; experiment in vivarium conditions).

*, ** Differences with control are statistically significant with $\mathrm{p} \leq 0.05$ and $\mathrm{p} \leq 0.01$.

The assessment of the total intake of chemical elements with food and the increase of their total pool allowed us to calculate the specific share accumulated in chickens for the test period. It was ascertained that with the use of nanoparticles the iron retention from food reached $50.0 \%$ and that of cobalt was $34.7 \%$. It is in line with the results of M.F. Aslam et al. [23) obtained when using the preparations of iron nanoparticles and is naturally related to the specifics of cellular uptake of nano- and soluble forms of metals [23]. It is well known that iron can be intestinally absorbed by means of endocytosis as part of complex aggregates, for example, vegetable-derived ferritin. Ferritin may contain several thousand iron atoms [24, 25]. Metal nanoparticles are transported, in particular, by endocytosis [23]. This phenomenon is well described in the literature. The intensity of metal release from nanoforms is lower as compared to ionic forms, which suggests that nanoparticles of metals are a better alternative to mineral salts (for example, as a source of microelements). The relatively slow release of iron from nanoforms and the preserved content of this element in blood make sure there is no homeostatic pressure on the iron exchange as a reason for the oxidative stress. It may be an advantage in case of substantial iron consumption in the digestive tract, which is observed after the absorption of therapeutic doses of soluble iron [26, 27]. The lower capability of enterocytes to retain metals in the form of nanoparticles as compared to the ionic form also plays a certain role [28].

There are no grounds to believe that the regulation of $\mathrm{Fe}$ exchange released after the degradation of $\mathrm{Fe}+\mathrm{Co}$ nanoparticles and from $\mathrm{FeSO}_{4}$ will be based on various mechanisms. Given this, the increase in the total iron pool in the organism when using the preparation of nanoparticles should be considered as a result of relatively slow release of this element from the nanoform.

The identified increase in the iron pool in group II was not associated with the significant growth of blood iron concentration as compared to group I (Table 1). It may be related to homeostatic reactions regulating the amount of iron in biological fluids (it is known that excessive iron may lead to the gen- 
eration of reactive oxygen species) [29]. At the same time the iron deficient diet fed to control chickens was accompanied by reduced iron concentration in blood as compared to group I and group II by $78.3 \%(\mathrm{p}<0.01)$ and $74.3 \%$ $(\mathrm{p}<0.01)$, respectively.

Slight changes of hemoglobin content in the blood of chickens from group I and group II correspond to the research on Swiss mice (CD1) (30) showing that nano-Fe (III) by its ability to efficiently recover the amount of hemoglobin is very similar to iron sulfate.

1. Blood morphology and biochemical indicators of 42-day old Smena 7 broiler chickens with the diet including $\mathrm{Fe}$ and Co salts (group I) or nanoparticles of Fe and Co alloy (group II) $(M \pm m, n=15$, experiment in vivarium)

\begin{tabular}{l|c|c|c}
\hline \multicolumn{1}{c|}{ Parameter } & $\begin{array}{c}\text { Control (without } \\
\text { supplements) }\end{array}$ & Group I & Group II \\
\hline Iron, mmol/l & $15.2 \pm 0.40$ & $27.1 \pm 0.25^{*}$ & $26.5 \pm 0.75^{*}$ \\
Hemoglobin, g/l & $95.6 \pm 1.01$ & $98.0 \pm 1.63$ & $101.0 \pm 1.01^{*}$ \\
Erythrocytes, $\times 10^{12} / 1$ & $2.1 \pm 0.13$ & $2.6 \pm 0.13$ & $2.6 \pm 0.12$ \\
Leucocytes, $\times 10^{9} / 1$ & $16.3 \pm 1.76$ & $19.5 \pm 1.13$ & $21.0 \pm 1.09^{*}$ \\
Glucose, $\mathrm{mmol} / \mathrm{l}$ & $6.3 \pm 0.27$ & $6.4 \pm 0.23$ & $8.6 \pm 0.15^{*}$ \\
Cholesterol, $\mathrm{mmol} / 1$ & $3.6 \pm 0.05$ & $4.4 \pm 0.27$ & $4.3 \pm 0.37$ \\
Urea, mmol/l & $1.3 \pm 0.02$ & $1.8 \pm 0.06^{*}$ & $1.5 \pm 0.10$ \\
Total protein, g/l & $33.3 \pm 1.20$ & $33.0 \pm 2.51$ & $37.3 \pm 1.28^{*}$ \\
Alkaline phosphatase, $\mathrm{nmol} \cdot \mathrm{sec}^{-1} \cdot \mathrm{l}^{-1}$ & $343.6 \pm 24.86$ & $336.6 \pm 17.39$ & $423.3 \pm 16.36$ \\
Creatinine, $\mu \mathrm{mol} / 1$ & $31.3 \pm 1.66$ & $51.3 \pm 1.49^{*}$ & $43.3 \pm 1.73^{*}$ \\
Bilirubin, $\mu \mathrm{mol} / \mathrm{l}$ & $3.5 \pm 0.27$ & $3.6 \pm 0.02$ & $1.1 \pm 0.05$ \\
${ }^{*}$ Differences with control are statistically significant with $\mathrm{p} \leq 0.05$. & & \\
\hline
\end{tabular}

We have found the increase of creatinine in blood by $63.9 \%(\mathrm{p} \leq 0.01)$ in group I and by $38.3 \%(\mathrm{p} \leq 0.05)$ in group II. Moreover, the chickens from group I had a higher concentration of urea by $38.5 \%(\mathrm{p} \leq 0.05)$, and in group II the amount of glucose exceeded that in the control group by $36.5 \%(\mathrm{p} \leq 0.05)$.

2. Growth and food consumption in Smena 7 broiler chickens with the diet including $\mathbf{F e}$ and Co salts (group I) or nanoparticles of Fe and Co alloy (group II) ( $M \pm m$, $n=15$, experiment in vivarium)

\begin{tabular}{|c|c|c|c|c|c|c|}
\hline \multirow{3}{*}{ Group } & \multicolumn{4}{|c|}{ Live weight } & \multirow{2}{*}{\multicolumn{2}{|c|}{$\begin{array}{l}\text { Food consumption per } \\
1 \mathrm{~kg} \text { of weight gain }\end{array}$}} \\
\hline & \multicolumn{2}{|c|}{ total, $\mathrm{g}$} & \multicolumn{2}{|c|}{ gain for the experiment (days 14-42) } & & \\
\hline & day 14 & day 42 & $\mathrm{~kg}$ & to control, $\%$ & $\mathrm{~kg}$ & to control, \% \\
\hline Control & $262.3 \pm 7.5$ & $1523.3 \pm 10.4$ & $1.26 \pm 0.08$ & & 2.48 & \\
\hline I & $267.7 \pm 9.1$ & $1606.7 \pm 19.7$ & $1.34 \pm 0.11$ & 106 & 2.25 & 90.7 \\
\hline II & $266.7 \pm 12.7$ & $1661.3 \pm 10.9^{*}$ & $1.40 \pm 0.09$ & 111 & 2.14 & 86.3 \\
\hline
\end{tabular}

The iron and cobalt in the diet was followed by higher intensity of chickens growth. In particular, for the test period the weight gain in group I exceeded the control indicators by $6 \%(\mathrm{p} \leq 0.05)$, and in group II - by $11 \%$ ( $\mathrm{p} \leq 0.001)$. Food consumption in the control group was higher by $9.3 \%$ and $13.7 \%$, respectively. Moreover, as compared to the effect of salts of these microelements, using their alloy in the form of nanoparticles increased the live weight gain by $4.1 \%(\mathrm{p} \leq 0.05)$ with reduced food consumption by $4.8 \%$ (Table 2 ).

Using nanoparticles was followed by an increase in the mass fraction of arginine in the liver of chickens from group II up to $8.1 \pm 0.105 \%$ as compared to control value $(5.05 \pm 0.075 \%)$ (Fig. 2).

It is generally in line with the previously obtained data [31, 32] on the biological effect of iron and copper particles on broiler chickens. It was ascertained that the intake of nanoparticles and microparticles $(\mathrm{d}=10-40 \mu \mathrm{m})$ was followed by the accumulation of arginine in the liver. It is known that arginine metabolism is closely related to the development of inflammatory 
and oxidative stress [33, 34]. Arginine is one of the factors regulating the growth of young animals [35-37]. The growth stimulating effects of L-arginine are related to the changes in the balance of consumed and expended energy of fat or the reduced white fat growth. L-arginine activates the mitochondrial biogenesis and the development of brown adipose tissue [38]. A.M. Fouad et al. [39] showed the reduction of abdominal adipose tissue and the amount of circulating lipids in Cobb 500 cross broiler chickens under the influence of dietary L-arginine.
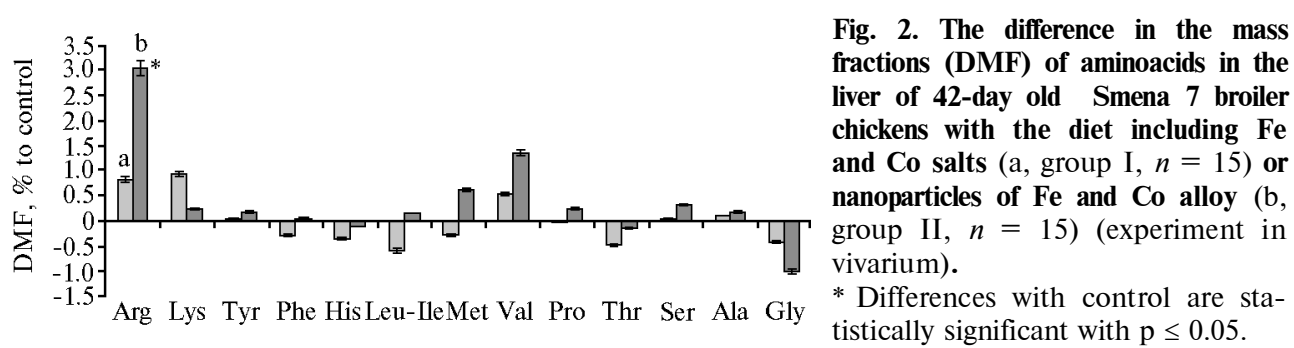

In our experiment, the use of nanoparticles of $\mathrm{Fe}$ and Co alloy did not result in critical accumulation of protein metabolism end products, in particular urea. At the same time, group I demonstrated a tendency towards the increase in these values with a statistically significant difference with control after administration of $\mathrm{Fe}$ and $\mathrm{Co}$ salts $(38.46 \%, \mathrm{p}<0.05)$.

The analysis of nitrogen containing compounds showed the intensified protein exchange after the intake of cobalt in various forms. The presence of cobalt in nanoparticles might become an additional factor in protein exchange activation. Earlier, similar results were reported by L.G. Kashirina et al. [40].

The use of the preparative form of nanoparticles (unlike salts) was followed by an increase in blood protein content by $12.0 \%(\mathrm{p} \leq 0.05)$ as compared to the control group. The growth rate of chickens from group II was significantly higher. The blood protein content in group I did not differ from the control group.

An essential factor of intensification was the higher food digestibility. In particular, in group II the digestibility of food protein grew by $3.1 \%$ ( $\mathrm{p} \leq 0.01)$, and that of carbohydrates - by $2.3 \%(\mathrm{p} \leq 0.05)$. The differences between the control group and group I were statistically invalid.

Thus, the research supports the proposed approach to optimizing the mineral diet of poultry by using alloys of nanosized antagonist microelements. It is known that in solutions metal salts dissociate, hydrate and become physiologically non-available. Moreover, unconjugated iron is an inductor of lipid peroxidation and peroxide protein distruction. Metals in nanoparticles, if they release gradually, will have a higher availability and their toxic effect will be reduced to the minimum. This may be the reason for the observed positive effect on growth in weight and certain increase in the hemoglobin content in chickens at administration of the nanopreparation. In our opinion, the revealed experimental facts evidence a higher availability and productive effect of the $\mathrm{Fe}$ and Co alloy nanoparticles as compared to the mineral salts of these elements.

\section{R E F E R E N C ES}

1. G o y e r R.A. Toxic and essential metal interactions. Annu. Rev. Nutr., 1997, 17: 37-50.

2. Notova S.V., Miroshnikov S.A., B olodurina I.P., Didikina E.V. Vestnik Orenburgskogo gosudarstvennogo universiteta, 2006, S2: 59-63 (in Russ.).

3. Xin W., Xugang S., Xi e C., Li J., Hu J., Y in Y.-1., D eng Z.-y. The acute and chronic effects of monosodium l-glutamate on serum iron and total iron-binding capacity in the jugular artery and vein of pigs. Biol. Trace. Elem. Res., 2013, 153: 191-195 (doi: 
10.1007/s12011-013-9668-x).

4. Sukhanova O.N., Mi roshnikov S.A., Kvan O.V. Vestnik myasnogo skotovodstva, 2011, 3(64): 87-92 (in Russ.).

5. Kudrin A.V., Skal'nyi A.V., Zhavoronkov A.A., Skal'naya M.G., $\mathrm{G}$ ro mova O.A. Immunofarmakologiya mikroelementov [Immunopharmacology of microelements]. Moscow, 2000 (in Russ.).

6. Hu a ng R.L., Y i n Y.L., Wu G.Y., Zhang Y.G., Li T.J., Li L.L., Li M.X., T a ng Z.R., Zhang J., Wang B., He J.H., Ni e X.Z. Effect of dietary oligochitosan supplementation on ileal digestibility of nutrients and performance in broilers. Poultry Sci., 2005, 84(9): 13831388 (doi: 10.1093/ps/84.9.1383).

7. F a ng R.J., Y i n Y.L., Wa ng K.N., H e J.H., C h e n Q.H., Fan M.Z., Wu G.Y. Comparison of the regression analysis technique and the substitution method for the determination of true phosphorus digestibility and faecal endogenous phosphorus losses associated with feed ingredients for growing pigs. Livestock Sci., 2007, 109: 251-254 (doi: 10.1016/j.livsci.2007.01.108).

8. Reddy M.B., H u r re 11 R.F., C o o k J.D. Estimation of nonheme-iron bioavailability from meal composition. Am. J. Clin. Nutr., 2000, 71(4): 937-943.

9. L a z a r e v M.I., E $\mathrm{n}$ i $1 \mathrm{e}$ e v R.Kh. Vitaminno-mineral'nyi kompleks. Patent RF 2195269. Rossiiskaya Federatsiya A61K31/00. Zayavl. 14.02.2001. Opubl. 27.12.2002. Byul. № 26 [Vitaminmineral complex. Patent RF 2195269. Russian Federation A61K31/00. Appl. February 14, 2001. Publ. December 27, 2002. Bul. № 26] (in Russ.).

10. Li nd T., Lönnerdal B., Stenlund H., Gamayanti I., Is mail D., Ses wa ndhana R., Pers on L.A. A community based randomized controlled trial of iron and zinc supplementation in Indonesian infants: effects on growth and development. Am. J. Slin. Nutr., 2004, 80: 729-736.

11. Shikh E.V., R a me nskaya G.V., Greben shchikova L.Yu. Lechebnoe delo, 2010, 4: 17-22 (in Russ.).

12. Bogoslovskaya O.A., Sizova E.A., Polyakova V.S., Miroshnikov S.A., Le i p unski i I.O., O l'k hovskay a I.P., G lu sh che n k o N.N. Vestnik Orenburgskogo gosudarstvennogo universiteta, 2009, 2: 124-127 (in Russ.).

13. Nikonov I.N., Folmanis Yu.G., Folmanis G.E., Kovalenko L.V., Lap t e v G.Yu., Eg o rov I.A., F is i $n$ i n V.I., T a $n$ a $n$ a e v I.G. Doklady akademii nauk, 2011, 440(4): 565-569 (in Russ.).

14. Raspopov R.V., Trushina E.N., Gmoshinski I.V., Khotimchenko S.A. Voprosy pitaniya, 2011, 80(3): 25-30 (in Russ.).

15. Ku reneva V.P., Egorov I.A., Fedorov Yu.I., G 1 us h chenko N.N., Fatku 1 1 i n a L.D. Sposob kormleniya tsyplyat. Patent SSSR 1346114. Soyuz Sovetskikh Sotsialisticheskikh Respublik A23K. Zayavl. 24.07.84. Opubl. 23.10.87. Byul. № 39 [A method of feeding chickens. Patent USSR 1346114. The Union of Soviet Socialist Republics A23K. Appl. July 24, 1984. Publ. October 23, 1987. Bul. № 39] (in Russ.).

16. O ro b che n k o A.L. Veterinariya, zootekhniya i biotekhnologiya, 2014, 10: 26-38 (in Russ.).

17. Orobchenko A.L., Roman'ko M.E., Kutsan A.T. Veterinariya, zootekhniya $i$ biotekhnologiya, 2014, 12: 32-40 (in Russ.).

18. F is in in V.I., Eg or ov I.A., M u k hin a N.V., C he rk a i Z.N. Materialy XVII Mezhdunarodnoi konferentsii VNAP «Innovatsionnye razrabotki $i$ ikh osvoenie $v$ promyshlennom ptitsevodstve» [Proc. XVII Int. Conf. WSAP «Innovative developments in poultry and their practical use»]. Sergiev Posad, 2012: 268-271 (in Russ.).

19. S mith R.M. Cobalt. In: Trace elements in human and animal nutrition. V. 1. W. Mertz (ed.). Academic Press, Inc., San Diego, California, 1987: 143-183.

20. Un d e rw o o d E.J. Cobalt. Nutr. Rev., 1975, 33(3): 65-9.

21. Zhigach A.N., Leipunski i I.O., Kuskov M.L., Stoenko N.I., S toroz h e v V.B. Pribory i tekhnika eksperimenta, 2000, 6: 122-127 (in Russ.).

22. Fis in in V.I., Egorov I.A., Le nkova T.N., Okolelova T.M., Ignatova G.V., Shevyakov A.N., Panin I.G., Grechishnikov V.V., Vetrov P.A., A f a n a s'e v V.A., P o n o m a r e n k o Yu.A. Metodicheskie ukazaniya po optimizatsii retseptov kombikormov dlya sel'skokhozyaistvennoi ptitsy. VNITIP [Guidelines for the optimization of feed recipes for poultry. VNITIP]. Moscow, 2009 (in Russ.).

23. Aslam M.F., Frazer D.M., Faria N., Bruggraber S.F., Wilkins S.J., Mirciov C., Powe 11 J.J., Anderson G.J., Pereira D.I. Ferroportin mediates the intestinal absorption of iron from a nanoparticulate ferritin core mimetic in mice. FASEB J., 2014, 28(8): 3671-3678 (doi: 10.1096/fj.14-251520).

24. Arosio P., Carmona F., Gozzelino R., Maccarinelli F., Poli M. The importance of eukaryotic ferritins in iron handling and cytoprotection. Biochem. J., 2015, 472(1): 1-15 (doi: 10.1042/BJ20150787).

25. Liu X., Th e il E.C. Ferritin as an iron concentrator and chelator target. Ann. NY Acad. Sci., 2005, 1054: 136-140. 
26. Hu rre 11 R.F. Safety and efficacy of iron supplements in malaria-endemic areas. Ann. Nutr. Metab., 2011, 59: 64-66.

27. Lomer M.C., Cook W.B., Jan-Mohamed H.J., Hutchinson C., Liu D.Y., $\mathrm{Hide} \mathrm{r} \mathrm{R.C.,} \mathrm{Powe} 11$ J.J. Iron requirements based upon iron absorption tests are poorly predicted by haematological indices in patients with inactive inflammatory bowel disease. $B r . J$. Nutr., 2012, 107, 1806-1811 (doi: 10.1017/S0007114511004971).

28. Pereira D.I., Mergler B.I., Faria N., Bruggraber S.F., Aslam M.F., Poo t s L.K., Prassmaye r L., Lo nnerdal B., B rown A.P., Powe 11 J.J. Caco-2 cell acquisition of dietary iron (III) invokes a nanoparticle at endocytic pathway. PLoS ONE, 2013, 8: 81250 (doi: 10.1371/journal.pone.0081250).

29. N e m m a r A., B e ega m S., Yuvaraju P., Yasin J., Ta ri q S., A t toub S., Ali B.H. Ultrasmall superparamagnetic iron oxide nanoparticles acutely promote thrombosis and cardiac oxidative stress and DNA damage in mice. Part. Fibre Toxicol., 2016, Apr 30, 13(1): 22 (doi: 10.1186/s12989-016-0132-x).

30. Latunde-Dada G.O., Pereira D.I., Tempest B., Ilyas H., Flynn A.C., A s 1 a m M.F., S i m p s o $n$ R.J., P o w e 11 J.J. A nanoparticulate ferritin-core mimetic is well taken up by HuTu 80 duodenal cells and its absorption in mice is regulated by body iron. $J$. Nutr., 2014, 144(12): 1896-1902 (doi: 10.3945/jn.114.201715).

31. Sizova E., Yausheva E., Kosyn D., Miroshnikov S. Growth enhancing effect of intramuscular injections with nano- and microparticles of elemental iron. Modern Applied Science, 2015, 9(10): 17-26 (doi: 10.5539/mas.v9n10p17).

32. Miroshnikov S.A., Yausheva E.V., Sizova E.A., Miroshnikova E.P., L e v a h i n V.I. Comparative assessment of effect of copper nano- and microparticles in chicken. Oriental Journal of Chemistry, 2015, 31(4): 2327-2336 (doi: 10.13005/ojc/310461).

33. H u a ng C.C., Ts a i S.C., Li n W.T. Potential ergogenic effects of L-arginine against oxidative and inflammatory stress induced by acute exercise in aging rats. Exp. Gerontol., 2008, 43(6): 571-577 (doi: 10.1016/j.exger.2008.03.002).

34. Mostafavi-Pour Z., Zal F., Monabati A., Vessal M. Protective effects of a combination of Quercetin and vitamin E against cyclosporine A-induced oxidative stress and hepatotoxicity in rats. Hepatol. Res., 2008, 38(4): 385-392 (doi: 10.1111/j.1872-034X.2007.00273.x).

35. Wu G., Ott T.L., Knabe D.A., B a z e r F.W. Amino acid composition of the fetal pig. J. Nutr., 1999, 129: 1031-1038.

36. Wu G., Knabe D.A., K i m S.W. Arginine nutrition in neonatal pigs. J. Nutr., 2004, 134: 2783S-2790S.

37. Fly n n N.E., M e i n i nge r C.J., H a y e s T.E., W u G. The metabolic basis of arginine nutrition and pharmacotherapy. Biomed. Pharmacother., 2002, 56: 427-438 (doi: 10.1016/S0753-3322(02)00273-1).

38. McKnight J.R., S atterfield M.C., Jobgen W.S., Smith S.B., Spencer T.E., Meininger C.J., Mc Neal C.J., Wu G. Beneficial effects of L-arginine on reducing obesity: potential mechanisms and important implications for human health. AminoAcids, 2010, 39(2): 349-357 (doi: 10.1007/s00726-010-0598-z).

39. Fou a d A.M., E 1-S e n ous e y H.K., Yang X.J., Y a o J.H. Dietary L-arginine supplementation reduces abdominal fat content by modulating lipid metabolism in broiler chickens. Animal, 2013, 7(8): 1239-1245 (doi: 10.1017/S1751731113000347).

40. K a s h i ri n a L.G., D e n i k i n S.A. Vestnik Krasnoyarskogo GAU, 2014, 4: 203-207 (in Russ.). 